\title{
Internationalization at Canadian Universities: Progress and Challenges
}

\author{
Linda Weber, University of Western Ontario
}

\begin{abstract}
The world-wide demand for international education continues to grow and Canadian universities are rising to meet this need. The rationales for internationalization are many and are culturally, politically, academically, and economically based. An overview of the current state of internationalization, its initiatives and programs at Canadian universities is outlined. Some of the challenges of internationalization include a lack of resources and a need for university-wide centralized and collaborative leadership for incoming international students, and study abroad programs. University staff and faculty would benefit from availing themselves of intercultural training provided through their university international offices. Many Canadian universities fully support internationalization in their strategic plans yet have less developed plans of how to implement internationalization into the teaching, support and service dimensions of the university. A case study describes how a mid-sized Catholic affiliated public university college in Ontario is implementing international programs and services for students. Cooperative and experiential learning theories are utilized as a means of guiding implementation.
\end{abstract}

\section{Résumé}

La demande universelle pour l'éducation internationale continue à s'agrandir et les universités canadiennes se montrent à la hauteur de la situation. Il y a plusieurs raisons pour cette internationalisation et elles sont de bases culturelle, politique, universitaire et économique. L'auteur esquisse ici une vue d'ensemble de l'état actuel de cette internationalisation, ses initiatives et ses programmes dans les universités canadiennes. Quelques-uns des défis de cette internationalisation comprennent un manque de ressources et le besoin d'une direction centralisée et collaborative entre les universités pour les programmes d'accueil des étudiants internationaux au Canada et pour les Canadiens qui étudient à l'étranger. La formation interculturelle fournie par les bureaux internationaux des universités ferait du bien aux membres enseignants des universités et aux facultés. Dans leurs plans stratégiques, plusieurs universités canadiennes soutiennent complètement l'internationalisation, mais elles n'ont pas développé les projets pour réaliser l'internationalisation dans toute l'étendue de leur enseignement, leur soutien et de leur service. Par une étude de cas l'auteur décrit comment une faculté catholique de taille moyenne affiliée avec l'université de Western Ontario réalise ses programmes d'internationalisation et offre ses services aux étudiants. Les théories d'apprentissage basées sur l'expérience et sur la coopération sont utilisées pour guider cette réalisation. 


\section{Introduction}

The importance of international education in higher education has been recognized for many decades but internationalization has only appeared in literature and practice in the past two decades (Knight, 2000). There is a high level of consensus among Canadian institutions that to "prepare graduates who are internationally knowledgeable and interculturally competent” is the key rationale behind internationalization efforts. Seventy-three percent of responding institutions in the Association of Universities and Colleges of Canada (AUCC) Report on Internationalization at Canadian Universities ranked this as first in importance as a rationale for internationalization at Canadian universities (Knight, 2000). Eighty-four percent of institutions reported that internationalization was already part of their university-wide strategy or long-term planning document (Knight, 2000), indicating that Canadian universities are keenly aware of their need to internationalize and are actively engaged in international education initiatives.

The Canadian Bureau of International Education (CBIE) defines international education as "a set of activities that link people and educational institutions across borders, both virtually and in person, for the purpose of sharing knowledge and of creating networks for the expansion and distribution of knowledge” (Farquhar, 2001, p.1). The concept of globalization has by some, been distinguished by its association with economic forces such as trade, finance and investment (McCabe, 2001). Knight (2003) broadens this concept and adopts the definition of globalization as the flow of technology, economy, knowledge, people, values and ideas... across borders. The concept of globalization is complex and contested (Yang, 2005). Two main approaches to the concept of globalization can be distinguished. The first is politically neutral and defines globalization as an empirical reality in terms of the compression of time and space, particularly as associated with communications technology. The second approach identifies globalization as an economic discourse which actively promulgates a market ideology (Yang, 2005). It is important to discuss globalization in a way that is open to resistance, contestation and difference. There is a need to look at globalization as an impetus for homogeneity and also as a stimulus for the production of difference (Rezai-Rashti, 2004).

The term international conveys the sense of relationships between and among nations, cultures, or countries (Knight, 2003). Knight (2003) proposes the following working definition of internationalization of higher education: "Internationalization at the national, sector, and institutional levels is defined as the process of integrating an international, intercultural, or global dimension into the purpose, functions or delivery of postsecondary education.” This process has far reaching implications and affects all aspects of post-secondary teaching, research, and service. Robert Giroux, president of AUCC in the year 2000, indicates that internationalization today means more than interpersonal or interinstitutional cooperation across borders. "It is a necessary, vital, and deliberate transformation of how we teach and learn and it is essential to the future quality of higher education in Canada, indeed to the future of Canada. In a world 
characterized by challenges and opportunities of global proportions, universities are key agents of change.” (Knight, 2000, p. 2)

Currently there are 90 universities in Canada with membership in the Association of Universities and Colleges of Canada (AUCC, 2005). Canadian universities, large and small, are actively participating in international education. AUCC (2005) reports that Canadian universities have more than 3500 exchange agreements with universities in 142 other countries. More than 70000 international students attend Canadian universities and these students are considered to be Canada's future commercial, research and diplomatic partners (AUCC, 2005). In 2001-02, there were 32779 Canadian students studying abroad, representing $3.7 \%$ of the domestic university student population. At the same time, the total number of international students across all provinces as a percentage of total university enrollment was 5.9\% (Savage, 2005).

The world wide demand for international education remains high and continues to grow. The Global Student Mobility 2025 Report predicts that the demand for international education will increase from 1.8 million international students in 2000 to 7.2 million international students in 2025 (Knight, 2005). The financial incentives for international education are also remarkably high. It is claimed that, worldwide, "the market value is $\$ 30$ billion a year for study abroad and $\$ 60$ billion for all international education and training products and services...." (CBIE 1998, p. 12). Foreign students contribute approximately $\$ 4$ billion a year to Canada’s economy (Citizenship and Immigration Canada, 2006).

Despite the high numbers of international students and international exchanges in Canadian universities, many challenges to internationalization remain. Bond, Qian, and Huang (2003) indicate that there is little evidence (with some notable exceptions) that the internationalization priorities are supported by everyday academic practice and institutional policies at universities. It does not appear that there is a lack of vision or international education opportunities that has led many to see an underachievement in the internationalization of Canadian education; rather there seems to inadequate investment in the internationalization process itself (Vertesi, 1999). Yet, despite underachievement in implementing internationalization, many universities are actively involved in internationalization and in educating citizens for global awareness (Astiz, 2007).

\section{Rationale for internationalization}

Farquhar (2001) outlines four kinds of rationale for internationalizing Canadian universities. These rationale are culturally, politically, academically, and economically based. The culturally based rationale is based on the assumptions that the better Canada's culture is understood, the more highly respected it will be in the global arena and the higher its international influence; and that Canadian values include the recognition of responsibility to help less fortunate nations through education (Farquhar, 2001). Some of the challenges of globalization, interdependence and multiculturalism, include the reality that, although the processes of globalization and modernization developed simultaneously throughout the planet, there are "globalizers" and the "globalized" and this 
development has brought a situation of profound and increasing inequality between nations (Gacel-Avila, 2005). This raises the question of how Canadians can assume responsibility to use their international influence to equalize power imbalances throughout the world. A challenge for Canadians, and any "globalizing" nation, is to interact in a respectful manner that does not impose Canadian culture or influence on others.

International education is also endorsed for political reasons such as the rationale that Canada's security depends on Canadians' familiarity with the motivations of foreign leaders, with other countries' political structures and historical systems, and with strategic alliances and animosities among them (Farquhar (2001). Governments can play a vital role in the development of international education and support. Rizvi (2004), writing about offshore Australian higher education, indicates that the Australian government became a vocal champion of offshore education because it views this education as valuable in the promotion of economic and political interests, especially in performing public diplomacy within the Asian-Pacific region. The Canadian government also supports the internationalization of Canadian universities. Monte Solberg, Minister of Citizenship an Immigration stated that, "Foreign students make a significant contribution to Canada. They enrich campus and community life with new ideas and new cultures, and they are an important pool of potential future skilled workers that Canadian businesses need to remain competitive." (Citizenship and Immigration Canada, 2006). The claim that Canadians need international students to maintain a competitive labour force sends a strong message to Canadian universities recruiting students.

A third rationale is academic and includes such arguments as: a) the quality of higher education is enhanced by the infusion of international elements into the content of all curricula, by expanding foreign language programs, and by capitalizing on the linguistic and cultural diversity of international students; and b) the international exchange of scholars extends expertise and fosters the academic strength of host and home institutions. In Canada and elsewhere Canadian universities have long been involved in the international front producing and disseminating knowledge on a universal scale. Universities have supported researchers' efforts to integrate themselves into the international scientific community, publish in the best journals, and secure a place in academic disciplines (Lemasson, 1999). Lemasson (1999) suggests that one may say that scientific activity was "globalized" long before the world of business and economics. However, although the mission of universities is international by nature, this does not mean that a given institution can be considered "internationalized". If a Canadian university is to be internationalized its teaching and service to the community also needs to have an international orientation (Lemasson, 1999).

The fourth category of rationale is economic in nature. The Conference Board of Canada found the following: a) countries that have a more coordinated national approach to international education reap greater economic benefits; $b$ ) involvement in international education is positively correlated with economic 
performance, and c) international education activity, as measured by student outflows, has a strong positive impact on the rate of gross domestic product growth (Farquhar, 2001). The economic rationale for internationalization can be, for some, the most compelling rationale for internationalization at Canadian universities. It may also be the most controversial or fraught with the possibility of difficulty because universities who recruit for primarily financial reasons may not adequately invest in the resources and services international students require. Today's university resembles that of the early 1950s in the respect that its lack of adequate financial resources restricts the institutions (Clark, 1999). Increasing foreign student enrollment may be an effective means of securing a financial base within universities. Yet if adequate teaching, service and research infrastructures are not in place for foreign students, and if monetary gains take precedence over issues of transnational curriculum and pedagogy, universities' formative mission to promote public good risks being undermined (Rizvi, 2004).

\section{Study abroad opportunities for Canadian students}

Another way Canadian universities promote internationalization on their campuses is through the promotion of exchange programs for their domestic students. Bob Rae in his report Ontario: A Leader in Learning (2005) recommended increased opportunities for Ontario students to study abroad. Rae proposed a new five million dollar Ontario International Study Program fund for 2005-06 that would rise to ten million dollars in 2006-07. Funding would be made available to institutions for students to study outside Canada and institutions would guarantee appropriate credit recognition for the completion of courses. This governmental funding and institutional recognition is intended to assist in ensuring that students have equitable access to participation (Rae, 2005).

\section{Challenges of Study Abroad Programs}

There is strong support within Canadian universities for study abroad programs. In the AUCC Report of Internationalization at Canadian Universities, Knight (2000) found that $90 \%$ of responding Canadian post-secondary institutions indicated a medium or high interest in providing out-of-country experiences for Canadian students. Most Canadian students are studying in the United States or Western Europe. In 2001-02 the countries frequented by Canadian students studying abroad were: the United States (77.1\%); the United Kingdom (9.3\%); Australia (2.9\%); France (2.9\%); and Germany (1.3\%). The percentage of students studying in a country other than the U.S., Australia, or Western Europe was 3.2\% (Savage, 2005). This raises the question of the opportunity for students to live in cultures very different from their own. Students studying in cultures significantly different from their own have the advantage of being able to compare their culture with that of others, to challenge previously unrecognized ethnocentric views, and to develop a stronger understanding of self. Understanding one's own culture is always developed through interaction with others (Wagner, 1981; as cited in Yan \& Wong, 2005). "It is only in the eyes of another culture that foreign culture reveals itself fully and profoundly.” (Bakhtin, 1986, p. 7; as cited in Yan \& 
Wong, 2005) If we do not have the other to contextualize our experience, our understanding of ourselves remains incomplete (Yan \& Wong, 2005).

Study abroad programs are also helpful in internationalizing teacher education. (Howe, 2003; Schneider, 2003). Intercultural competence (the ability to work effectively in cross-cultural contexts) is increasingly recognized as important for educational professionals in today's globalized world (Wihak, 2006). Teacher education programs with a cross-cultural practicum experience have been shown to successfully incorporate comparative, international, and development education (CDIE) (Howe, 2003). Yet, comparative, international and development education (CDIE) courses are usually only offered within graduate programs at Canadian universities (Howe, 2003). Howe (2003) argues that undergraduates within teacher education programs would benefit from CDIE courses taught within undergraduate courses. It can be further argued that undergraduates who have the opportunity to take CDIE courses are better prepared for study abroad experiences. If Canadian universities are sending undergraduates on study abroad experiences they have the responsibility to adequately prepare their students for these experiences.

\section{Attracting International Students to Canada}

There is an increased global demand for international higher education across the world (Rae, 2005). Other countries have demonstrated greater government leadership and funding to create broader marketing and accessibility strategies to attract international students. The United States receives 30\% of the global total of international students studying abroad, followed by Germany and the United Kingdom (12\% each), Australia (10\%), and France (9\%). Canada's total share of postsecondary international students is less than $1 \%$.

One of the ways the Canadian government is attempting to attract more international students to Canada is to allow them to obtain off-campus work permits. On April, 27, 2006 the Minister of Citizenship and Immigration (CIC) announced that foreign students studying in Canada could apply for off-campus work permits effective immediately (CIC, 2006). International students are now permitted to work off campus while they are studying and for two years after graduation (provided they do not take a job in Montreal, Toronto, or Vancouver) without having to change their study permit. Citizenship and Immigration Canada (2006) reports that in 2005, more than 50,000 new foreign students came to Canada to study in post-secondary institutions. The numbers of international students in Canadian post-secondary institutions are rapidly increasing. With rapidly increasing numbers of international students studying at Canadian universities faculty, administration, staff and students at universities will need to develop increased skills and understandings in internationalization and intercultural relations.

\section{Challenges internationalizing Canadian universities}

Mobilizing faculty and internationalizing curricula are still challenges that need attention if academic benefits of internationalization are to be captured more fully. 
Survey respondents held the view that a strong level of interest among faculty and staff is the single most important organizational factor affecting internationalization (Knight, 2000). Yet only 21 percent of responding institutions include international or intercultural expertise or achievements in performance reviews, 19 percent address international accomplishments in promotion policies and 14 percent identify international work and achievements in tenure procedures. In terms of curriculum change the survey found that overall there appears to be a low level of interest and support by faculty members. Only forty percent of respondents reported that a process to review and monitor efforts to internationalize the curriculum is in place or under development.

\section{A framework for action}

Internationalization within Canadian universities reaches beyond student exchange programs and recruitment of international students.

In the context of higher education, internationalization is a multifaceted phenomenon, pervasive throughout the institution, and touching all aspects of the university mandate. It impacts on what is taught in the classroom, on how students learn, and on the make-up of the student body and professoriate. The impact of global interdependence is also reflected in research activities, reading lists, case studies, opportunities offered to students as well as in the activities and services offered to the wider community. (AUCC Statement, 1995, p. 3).

A commitment to internationalization is necessary at all levels within the university. A commitment at senior levels of administration is an important step but not enough. Internationalizing Canadian universities is both a bottom up and top down process (AUCC, 1995). In her work within and between diverse cultures, Delpit (1995) concluded that members of any culture transmit information implicitly to co-members. Members who are new to the culture frequently lack the skills to understand implicit codes of communication and benefit from being told explicitly the rules of a culture. Although Delpit's work was not done in a post-secondary context, it has implications for university international students who are new to a culture. Political, economic, or cultural understandings that may be common to a group of students who grew up in Ontario will not necessarily be shared by international students. International students change the dynamics of the Canadian university classroom and professors and students can no longer assume shared cultural understandings. Some Canadian students may find it tedious to have some of the cultural understandings they took for granted made explicit, yet many, it can be argued, will benefit from questioning cultural norms they may have assumed were universal in scope.

The merits or benefits of internationalization cannot be accepted without an understanding of Canada's responsibility to international students. Canadians are responsible to actively guard against institutionalized racism and be vigilant in confronting problems of inequality and ethnocentric ways of perceiving the world. There is much work still to be done. Alladin (1996) observes that there is an increasing awareness that Canadian society is multicultural and that the education 
system should prepare citizens to cope with national and global realities. Rattansi (1992), responding to the black presence in British education and society, says that if antiracism is to be effective in education it is necessary to take a hard, sometimes painful look at the terms under which we have operated so far. Rattansi (1992) asks how it will be possible to develop educational practices that build on existing multicultural and antiracist initiatives yet move beyond them. He suggests that these practices will have to take into account contradiction and ambivalence in the operation of racism, and avoid cultural and ethnic essentialisms and reductionisms. As well, educators will have to grapple with the limitations of rationalist pedagogies and assumptions about the translation of formal policies into practice. This will be a long and difficult task -- difficult but absolutely essential (Rattansi, 1992).

International students or Canadian students studying abroad begin to form new identities as they are influenced by the ideas and systems of the host culture. They become more aware of the interconnections and political and economic interdependencies between their host culture and "home" culture. Minority cultural identities are not fixed or monolithic. Rather, they are mulitivocal, even contradictory, and fluid. They derive from historically grounded experiences and practices (McCarthy, 1990). There is a growing recognition that we all speak from a particular place, out of a particular history, out of a particular experience, a particular culture, without being contained by that position (Hall, 1996). As university students participate in experiences outside their home culture they become more cognizant of how their ideas and identities have been shaped by their particular places and histories. International students return to their countries of origin changed, often with broader conception of their place within the global community. The longer students are in an unfamiliar culture, the more likely that their cognitive, affective and behavioural outlook will change. As the students adapt to a different culture, they will inevitably experience an incremental process of identity change (Ting-Toomey, 1999).

\section{Challenges in implementing internationalism}

The majority (60 percent) of post secondary institutions in Canada, surveyed in the AUCC report 2000, indicated that they did not have any process in place to review and assess the international and intercultural dimension of courses and programs offered at their universities. Fifteen percent of institutions reported that a review process was in place and 25 percent reported that one was being developed. This is indication that a low priority is being given to the internationalization of Canadian curriculum (Knight, 2000). However, Knight (2000) notes that there appears to be an increasing awareness and concern about this issue. The international dimension of the curriculum and teaching/learning process is a crucial element of internationalization. It is, in many ways, the most challenging aspect to implement in Canadian institutions and it is the most difficult to monitor and measure (Knight, 2000).

Leask (2001) provides a case study of how the University of South Australia internationalized all its courses so that all graduates would demonstrate 
an international perspective as professionals and citizens. The changes in the cultural profile of the student population predictably raised issues and challenges for academics as they strove to meet the needs of an increasingly diverse group of students (Leask, 2001). Challenges include cross-cultural communication issues, learning support, and provision of courses that are relevant to the needs of all student groups.

\section{Role of the University International Office}

One of the ways challenges to internationalization and meeting the needs of an increasingly diverse group of students is to involve the support services of University International Offices. University faculty, administration and staff can progress more effectively in internationalization efforts if they have training in place to assist them. More training would assist international education professionals within Canadian universities in their internationalization strategies. Knight (2000) observes that few respondents of the AUCC 2000 Report described the role that the international office plays in the promotion and facilitation of internationalizing the curriculum. Although university curriculum development and revision are the responsibilities of home departments or faculty, given the nature of the internationalization process, champions are needed to stimulate and reinforce the development or review of curriculum so that the international dimension is integrated where appropriate (Knight, 2000). Respondents of the AUCC report gave diverse responses to the role the international office held at their university. Queen's University International Centre (QUIC), at Queen's University in Ontario, found that the range of jobs that international educators hold in educational institutions, organizations, and companies across Canada vary tremendously (Myles, \& Corrie, 2004). Yet commonalities exist in these jobs that serve to create the foundation of an international education profession. After 60 years of increasing numbers of international students coming to Canada and internationalization activities around the world, the realization that an international education profession exists is still in early stages (Myles, \& Corrie, 2004). International educators at QUIC have developed a competency-based training program for international educators in Canada. Various Canadian professional associations are also working to serve practitioners in international education. Examples of Canadian Professional Associations include: the Association of Universities and Colleges of Canada (AUCC), the Canadian Bureau of International Education (CBIE), the Work/Study Abroad Network, the World University Services of Canada (WUSC), and Professional International Educators of Canada (PIECan). International Offices also function differently in smaller universities than they do in larger universities. At smaller universities, or at affiliated university colleges, much of the work that may be done by an International Office in a larger university is shared by various offices and departments within the university. 
Case Study of Internationalization at King's University College at The University of Western Ontario (KUC)

KUC is a Catholic University College affiliated with the University of Western Ontario. KUC's goal to promote the process of internationalization throughout the college is clearly stated in the Strategic Plan (King's University College, 2006). To achieve this goal, KUC created an Internationalization Working Group, consisting of administrators, professional officers, faculty and staff, as a forum to enhance discussions of internationalization, develop plans for resource sharing, identify needs, and develop program initiatives. The International Working Group fulfills the roles and responsibilities of an International Office. Numerous programs have been developed and established through this Internationalization Working Group. I am a member of this Working Group and will discuss some of the programs with which I am involved or familiar.

Using a case study approach (Merriam, 1998) I will describe how internationalization initiatives have been implemented at KUC. The case study design is utilized to gain a deeper understanding of the situation and meaning for those involved. Insights can be used to influence practice, policy and future research (Merriam, 1998). The processes, activities and understandings gleaned from this case study may assist others in implementing internationalization initiatives at other universities, or may provide an impetus for future study. The lenses through which I see and gathered information are in my roles as an International Student Advisor (including the responsibilities of international student program coordination, study abroad support, and the International Peer Guide Program) and as the Instructor of the Introduction to Canadian Culture course for international exchange students at KUC. As an investigator in a case study, and as a human instrument, my observations are limited by my lenses, and are filtered by my worldview, values and perspectives (Merriam, 1998)

\section{Cooperative Learning at KUC}

Two theoretical constructs that have guided my work have been those of cooperative learning (Luca \& Barney, 2002; Sullivan \& King, 1999) and experiential learning (Breunig, 2005; Kohonen, 2001; Kolb, 1984; Teranishi, 2007). Through cooperative learning students can be empowered to solve their own personal and social problems. This is relevant for international students because international students are less likely than domestic students to seek professional counselling assistance for personal concerns (Baloglu 2000). Many Asian students are reluctant to discuss personal or psychological difficulties with a professional (Lin \& Yi, 1997; as cited in Popadiuk \& Arthur, 2004). Friends have been found to be international students preferred source for help, followed by parents and teachers (Baloglu, 2000). For this reason peer support services that follow a cooperative learning model are especially useful for international students. The concept of learning through peer tutoring is based on the social constructivist view of learning. Students coach peers through social interactions (Vygotsky, 1978, as cited in Luca \& Clarkson, 2002). Learning is believed to occur on a social level when content becomes meaningfully and personally 
relevant and when a learner interacts with a more experienced mentor who leads the learner to a level of increased understanding (Hsu, 2004). The role of the student mentors is to facilitate rather than teach and the aim of learning is to solve practical problems in an authentic setting (Luca \& Clarkson, 2002). Research has shown that cooperative social support groups have been effective as a means of empowering students to solve their own personal and social problems (Sullivan \& King, 1999).

Applying cooperative learning to an international context, Westwood, at the University of British Columbia, and Barker, from the Australian International Development Assistance Bureau, compared academic achievement and social adaptation among international students who participated in a peer pairing program A significant relationship was found between Peer Program involvement and higher year end academic averages. As well there was a significant relationship between the amount of social interaction with host nationals and sojourner adjustment (Westwood \& Barker, 1990). The International Peer Guide Program at KUC operates according to the principles of cooperative learning. Each year upper year KUC students volunteer to pair with new incoming international students to offer guidance, assistance with crosscultural adjustment concerns and the development of friendships. In turn the Peer Guides learn about other cultures through their connections with the International Peers. International students indicate that the ability to learn cooperatively through the relationships they form with their Peer Guides greatly aids their adjustment process. Student peer mentors are also available for helping new students with learning skills, conversation groups, and writing tutoring.

Domestic students at KUC who participate in various study abroad or exchange programs engage in cooperative learning when they share their experiences abroad with other students and faculty at KUC. In October KUC hosts an International Exchange Fair where students learn about the various exchange opportunities available. Some of the cross-cultural exchange or study abroad experiences available to KUC students include: an organizational behaviour or macroeconomics course taught at the Dongbei University of Finance and Economics (DUFE) in Dalian, China; a fourth year experiential elective in Social Work in Mexico or Costa Rica; a French language immersion experience in Nice France; a Peace and Social Justice experiential course credit in El Salvador; and a service field trip, organized through a Student Council Club and the Peace and Social Justice Program, to the Dominican Republic. Numerous other experiential courses are available for credit through the Peace and Social Justice Program and through the Exchange Office at The University of Western Ontario. The Social Work Program, the Peace and Social Justice Program and Student Services at KUC all provide a structured forum for students to share and report on their experiences when they return to KUC. Domestic students who have not gone on exchange then have the opportunity to benefit from this form of cooperative learning. More than 96\% of Canada's domestic university student population does not study abroad (Savage, 2005), and this public sharing of the 
exchange experience encourages broader learning and internationalization within the entire community.

Other programs of cooperative or community learning at KUC include the Centre for Social Concern, the Centre for Creativity and the Centre for Catholic Jewish Learning. The Centre for Social Concern engages in research and public awareness around issues of social justice and peace in Canada and internationally. The Centre for Creativity supports endeavours of the arts across diverse disciplines and cultures, and the Centre for Catholic Jewish Learning is an interfaith initiative that explores ways to cooperate in a fruitful and respectful manner.

One of the highlights of the year is KUC's annual Cultural Festival. The Cultural Festival is a cooperative project that is sponsored by administrative offices at KUC, Students' Council, CultureWorks, an ESL school, and Food Services at KUC. Various student clubs, faculty groups, and community members join together to display cultural performing arts in the university and local communities. Hosting large scale events that celebrate diversity is one way that universities are responding to the need to increase students' intercultural sensitivity (Klak \& Martin (2003). In a study that evaluated the effectiveness of large scale events in affecting students' attitudes towards cultural difference, students' attitudes shifted on several dimensions of intercultural sensitivity in the direction of greater openness to other cultures (Klak \& Martin, 2003). I did not systematically study students' shift in attitudes in cultural sensitivity. However, informally, numerous international students reported to me that the Cultural Festival assisted them in developing more positive attitudes towards other cultures, and helped them to feel more valued within the community. Some international students indicated that participating in the Festival was pivotal to their adjustment and adaptation to Canada. The City also recognized the difference that the Cultural Festival and other community focused programs at KUC make and in 2007 honoured KUC with the City's Race Relations Award.

Experiential Learning

The paradigm of experiential learning where students connect personal and intellectual knowledge is becoming more prevalent in higher education (Eyler \& Giles; as sited in Teranashi, 2007). The notion of participation in education is not new. Dewey (1963; as cited in Jakubowski, 2003), writing about "progressive education", noted that active learning was essential for individuals to develop as citizens. In a cross-cultural context, the pedagogy of experiential learning has been implemented in study abroad programs (Teranishi, 2007) and through immersion field trips (Jakubowski, 2003). Experiential education can be defined as "a philosophy and methodology in which educators purposely engage with learners in direct experience and focused reflection in order to increase knowledge, develop skills, and clarify values (Association of Experiential Education, 2004; as cited in Breunig, 2005). Studies have found that experiential learning has assisted students in developing their identities, connectedness to community, understandings of diversity (Teranishi, 2007), and abilities to critically examine assumptions about self and society (Breunig, 2005; 
Jakubowski, 2003; King, 2004). Educational theories of experiential education and critical pedagogy intersect in their aim of developing a more socially just world (Itin, 1999; Kincheloe, 2004; as cited in Breunig, 2005). "Critically responsive" pedagogy invites involvement and can be realized through the utilization of a conceptual framework that incorporates experience, critical thinking, reflection and action (Jakubowski, 2003).

I will highlight two programs and a course that incorporate experiential learning and have been especially effective at KUC. The Bridging Program is a week long intensive orientation program for incoming exchange and degree students who will be studying in Canada for the first time. Staff and faculty members, throughout the university college, work together collaboratively to provide informative academic and service orientation sessions for the students. Students who participate in the program report that they feel more prepared for their academic year. Teaching faculty and support staff report that students are better able to adjust to their year and acclimatize to the many expectations of their first year in academia as a result of prior orientation training. For example, students are better able to avail themselves of academic counselors, academic support programs, their professors' drop-in hours, and residence and student services, because they have a clearer understanding of what services are available to them and how to access them.

In addition to providing international student orientation and training, last year KUC provided a two day training seminar for staff, professional officers and faculty who were interested in honing their intercultural competence skills. This training, provided by the Centre for Intercultural Communication, the University of British Columbia Continuing Studies, also used experiential learning concepts. Simulated learning experiences were utilized to assist staff and administration in understanding the challenges of living in a new culture. More than twenty KUC staff, professional and administrative officers attended this seminar and reported that they found the training valuable in further developing their competence in working with international students and in preparing them to participate in internationalization initiatives at KUC. Thus far, one of KUC's challenges has been in providing training and support in internationalization for faculty. At the time we offered the intercultural training seminar many faculty members could not attend. However, many faculty and administrators at KUC strongly support international programs, attend receptions for international students, participate in international student activities such as the Chinese/Korean Autumn Festival and the New Year Festival and promote exchange for outgoing and incoming students. The reporter for the Sing Dao Daily newspaper who attended KUC's Autumn Festival this year reported that it was the largest Autumn Festival celebrated in the region. It was well attended by Asian students, Canadian Peer Guides, and staff, administration, and faculty members. Many of the programs and the strong interest in internationalization at KUC are possible because financial and human resources have been allotted to these efforts.

Another prime example of experiential learning in practice at KUC is the "Introduction to Canadian Culture" class I teach to exchange students. Students in 
this class attend many cultural activities and participate in excursions that highlight Canadian life and culture. For example, as a part of the class, students travel to some of central Canada's major cities including Toronto, Ottawa, Montreal and Quebec City. They also visit rural Ontario villages and towns, a farm, a sugar bush, a pioneer village, an art gallery, premier theatre, sports events, and a museum of archeology. As a part of the Peer Guide Program they also participate in Canadian festivals and holidays and share their countries' holidays with the Peer Guides. Students are prepared for these excursions in class and have ample opportunity after the excursions to critically reflect upon their experiences through class instruction, discussion, and journal writing. Many of the students report that this experiential course has given them a fuller appreciation of Canadian culture, has prepared them for their other courses, and has augmented their adjustment and adaptation to life in Canada.

\section{Internationalization Challenges at KUC}

Despite the varied and numerous international programs and study abroad or exchange opportunities available at KUC, challenges to internationalization remain. International students report that it is difficult to form deeper friendships with Canadian students. Canadian students who have studied or lived in another culture are often most open to international students, and these students are more likely to participate in the Peer Guide Program and other international initiatives. This would appear to indicate that many Canadian students would benefit from exchange or study abroad opportunities, yet not all Canadian students have the money or the means to participate in experiences abroad. Living together in residence offers all students an opportunity to interact and engage in cross-cultural discussions, yet many students do not avail themselves of these opportunities. Most KUC domestic students do not avail themselves of the opportunity to share a room with an international student. Many Canadian students report that international students often remain within their own cultural groups and that it is difficult for them to know how to show interest and acceptance to individual students. Another challenge is that students who are most in need of the international services, be they international students who are struggling with adjustment, academic or personal issues, or domestic students who are more ethnocentric in their orientation and most in need of understanding diversity, are often least likely to avail themselves of the international programs and services offered. Further education and critical reflection may assist with some of these challenges.

\section{Conclusion}

Internationalization policies and implementation programs are in place at Canadian universities and the numbers of students participating in study abroad experiences and the numbers of international students studying in Canada are increasing yearly. The rationale for increasing internationalization efforts in Canadian universities are many, and are culturally, politically, academically, and 
economically based. Yet Canadians are in the early stages of the process or integrating an international dimension into the teaching, training, research and service functions of the university. Increased funding is being made available to internationalize universities. If universities are to effectively meet the needs of their students this funding will need to be augmented with training of faculty, and in internationalizing of curricula. International education professionals are underutilized in Canadian universities. They have a pivotal role to play in training and increasing the international awareness throughout the university. Internationalization brings pervasive changes to Canadian universities. The case study cited is an example of substantial changes that have occurred within an affiliate university college, as a result of internationalization, within the past ten years. Ten years ago KUC had fewer than 10 international students and international students now comprise 10 percent of its population. KUC is not alone. Universities throughout Canada are rapidly adjusting to the changes brought about through internationalization. KUC offers an example of how cooperative learning and experiential learning theories can be employed to implement study abroad programs, and international student programs, and staff and faculty development within Canadian universities. For better or worse, the impact of global interdependence affects us all. Our institutes of higher learning have the potential to lead the way in creating a world of greater social and economic equality and greater intercultural knowledge and understanding for all.

\section{References:}

Alladin, I. (1996). Racism in Canadian schools. Toronto: Harcourt Bince.

Association of Universities and Colleges of Canada (AUCC). (2005). Canadian

Universities: Active around the world. Distributed Internationalizing Canada's Universities: A York Symposium, York University, March 3, 2006.

Astiz, M.F. (2007). The challenges of education for citizenship: Local, national, and global spaces. Comparative Education Review, Vol 51 (1), 116-124.

AUCC Statement on Internationalization and Canadian Universities. (1995). Retrieved from http:www.aucc.ca/publications/statements/1995/intl_04_e.html. April 12, 2005 ,

Association of Universities and Colleges of Canada (AUCC). (2005). Canadian universities: General information. Retrieved October 18, 2006, from http://www.aucc.ca/can uni/general info/overview e.html

Baloglu, M. (2000). Expectations of international students from counseling services. Paper presented at the Annual Conference of the American Psychological Assoication, 2000, Washington, DC). ERIC document ED 447372.

Bond, S., Qian, J., \& Huang, J. (2003). The role of faculty in internationalizing the undergraduate curriculum and classroom experience. CBIE Research Millennium Series No. 8. Ottawa: CBIE. 
Breunig, M. (2005). Turning experiential education and critical pedagogy theory into praxis. Journal of Experiential Education, Vol. 28 (2), 106-122.

Canadian Bureau for International Education (1998). Canada's participation in international education: Diagnostique. Ottawa: CBIE.

Citizenship and Immigration Canada (Ottawa, April 27, 2006). Off-Campus Work Permit Program Launched. From http://www.cic.gc.ca/english/press/06/0601-e.html on June 21, 2006.

Clark, H. (1999). The dilemma of institutional structures (pp. 99- 127). In S. Bond \& J.P. Lemasson (Eds.), A New World of Knowledge. Ottawa: International Development Research Centre.

Delpit, L. (1995). Other people's children: Cultural conflict in the classroom. New York: The New Press.

Farquhar, R. (2001). Advancing the Canadian Agenda for International Education: Report of the Millennium Consultation on International Education. Ottawa: Canadian Bureau for International Education.

Gacel-Avila, J. (2005). The internationalization of higher education: A paradigm for global citizenry. Journal of Studies in International Education, Vol. 9, No. 2, 121-136.

Hall, S. (1996). New ethnicities. In D. Morley and K.H.Chen (Eds.), Stuart Hall: Critical dialogues in cultural studies, (pp. 441-449). London: Routledge.

Howe, E. (2003). Curriculum, teaching and learning within the context of comparative, international and development education. Comparative and International Education, Vol. 32 (2), 1- 14.

Hsu, J.T. (2004). Reading without teachers: Literature circles in an EFL classroom. Paper presented at the Cross-Strait Conference on English Education. ERIC document ED 492558.

Jakubowski, L.M. (2003). Beyond Book Learning: Cultivating the pedagogy of experience through field trips. The Journal of Experiential Education, 26(1), 2433.

King, J. (2004). Service-learning as a site for critical pedagogy: A case of collaboration, caring and defamiliarization across borders. The Journal of Experiential Learning, 26 (3), 121-137.

King's University College (2006). Vision, Values, and Learning: A Strategic Plan for King's University College 2005-06. Retrieved on October 24, 2006 from: http://www.uwo.ca/kings/about/mission/index.html.

Knight, J. (2005). Crossborder Education: Programs and providers on the move. CBIE Millennium Research No. 10. Ottawa: Canadian Bureau for International Education.

Knight, J. (2003). Updating the definition of internationalization. International Higher Education. Center for International Higher Education, Boston College. Retrieved on October 18, 2006 from http://www.bc.edu/bc_org/avp/soe/cihe/newsletter/News33/text001.htm

Knight, J. (2000). Progress and Promise: The 2000 AUCC report on internationalization at Canadian universities. Ottawa: Association of universities and colleges of Canada.

Kohonen, V. (2001). Towards experiential foreign language education. In Kohonen, Jaatinen, Kaikkonin, \& Lehtovaara (Eds.), Experiential Learning in Foreign Language Education (pp. 8-60). Toronto: Longman Pearson Education. 
Kolb, D. (1984). Experiential Learning: Experience as a source of learning and development. Englewood Cliffs, NJ: Prentice Hall.

Leask, B. (2001). Bridging the gap: Internationalizing university curricula. Journal of studies in international education, Vol.5, No. 2, pp. 100-115.

Lemasson, J.P. (1999). Introduction: The internationalization of Canadian universities(pp. 1-19), In S. Bond \& J.P. Lemasson (Eds.), A New World of Knowledge. Ottawa: International Development Research Centre.

Luca, J. \& Clarkson, B. (2002). Promoting student learning through peer tutoring - A case study. ERIC document ED 477068.

McCabe, L. (2001). Globalization and Internationalization: The Impact on Education Abroad Programs. Journal of Studies in International Education, Vol. 5, No. 2, (pp. 138-145).

McCarthy, C. (1990). Multicultural education, minority identities, textbooks, and the Challenge of curriculum reform. Journal of Education 172(2), pp. 118-129.

Merriam, S.B.(1998). Qualitative research and case study applications in education. San Francisco: Jossey-Bass Publishers.

Myles, W., \& Corrie, S. Training for international educators in Canada: A competencybased approach. Kingston: Queen's University International Centre.

Popadiuk, N. \& Arthur, N. (2004). Counseling international students in Canadian schools. International Journal for the Advancement of Counselling, Vol. 26 (2), 125-145.

Rae, B. (2005). Ontario -- A Leader in Learning: Report and Recommendations. Ontario: Queen's printer for Ontario.

Rattansi, A. (1992). Changing the subject?: Racism, culture and education. In. J. Donald and A. Rattansi (Eds.), Race, Culture and Difference (pp.11-48).

Rezai-Rashti, G. (2004). Introduction. Canadian and International Education, Vol. 33(1), 1-5.

Rizvi, F. (2004). Offshore Australian Higher Education. Taken from: http://www.bc.edu/bc_org/avp/soe/cihe/newsletter/News37/text004.htm on January 26, 2006.

Savage, Christine (2005). The National Report on International Students in Canada 2002. The Canadian Bureau for International Education: Ottawa.

Schneider, A.I. (2003). Internationalizing teacher education: What can be done? A research report on the undergraduate training of secondary school teachers. (ERIC Document No. 480 869). Washington, D.C.: Department of Education.

Sullivan, A. \& King, L. (1999). An investigation into empowering students through cooperative learning. Paper presented at the annual meeting of the American Educational Research Association in Montreal Canada, April 1999. ERIC document ED 430180.

Sun, W. \& Chen, G. (1997). Dimensions of difficulties mainland Chinese students encounter in the United States. Paper presented at the International Conference in Cross-Cultural Communication. ERIC reproduction ED 408635.

Teranishi, C. (2007). Impact of experiential learning on Latino college students' identity, relationships, and connectedness to community. Journal of Hispanic Higher Education, Vol. 6 (1), pp. 52-72.

Ting-Toomey, S. Communicating across cultures. New York: The Guilford Press.

Vertesi, C. (1999). Students as Agents of Change. In S. Bond \& J.P Lemasson (Eds.) A New World of Knowledge: Canadian Universities and Globalization. International Development Research Centre, www.idrc.ca/es/ev-29566-201-1DO_TOPIC.html - 2006-04-15 
Westwood, M., \& Barker, M. (1990). Academic achievement and social adaptation among international students: A comparison groups study of the peer-pairing program. International Journal of Intercultural Relations, 14, 251-263.

Wihak, C. (2006). Learning to learn culture: The experiences of sojourners in Nunavut. Canadian and International Education, Vol. 35, No. 1, pp. 46- 62.

Yan, M.C., \& Wong, Y.R. (2005). Rethinking self-awareness in cultural competence: Toward a dialogic self in cross-cultural social work. Families in Society, 86 (2), 181- 188.

Yang, R. (2005). Internationalizing Chinese higher education: A case study of a major comprehensive university. In P. Ninnes \& M. Hellsten (Eds.), Internationalizing higher education: Critical explorations of pedagogy and policy, pp. 97-118.

Linda Weber (lweber@uwo.ca) is a Joint PhD doctoral candidate in education at The University of Western Ontario, as well as an International Student Advisor at King's University College at The University of Western Ontario. Research interests include international and domestic student responses to internationalization, intercultural learning and identity development. Of particular interest is how student identities develop and change through intercultural experiences. 